\title{
Urethral Cancer pT1 TNM Finding v7
}

National Cancer Institute

\section{Source}

National Cancer Institute. Urethral Cancer PT1 TNM Finding v7. NCI Thesaurus. Code C89374.

Urethral cancer with tumor invading subepithelial connective tissue. (from AJCC 7th Ed.) 